\title{
Coxiellosis in domestic livestock of Puducherry and Tamil Nadu: Detection of Coxiella burnetii DNA by polymerase chain reaction in slaughtered ruminants
}

\author{
Jothimani Pradeep ${ }^{1}$, Selvaraj Stephen ${ }^{1}$, Pratheesh Pooja ${ }^{2}$, Anbalagan Akshayavardhini ${ }^{2}$, Balakrishnan Sangeetha ${ }^{1}$ and \\ Prabakar Xavier Antony ${ }^{3}$ \\ 1. Department of Microbiology, Mahatma Gandhi Medical College \& Research Institute, Puducherry, India; 2. Department \\ of Genomics and Proteomics, Central Interdisciplinary Research Facility, Mahatma Gandhi Medical College \& Research \\ Institute, Puducherry, India; 3. Department of Veterinary Microbiology, Rajiv Gandhi Institute of Veterinary Education \\ and Research, Puducherry, India.
}

Corresponding author: Selvaraj Stephen, e-mail: stephens4950@gmail.com

Co-authors: JP: jpradeep2789@gmail.com, PP: poojapratheesh@gmail.com, AA: akshi.anbu@gmail.com, BS: sangeethabvs@gmail.com, PXA: pxantony@gmail.com

Received: 08-08-2016, Accepted: 03-05-2017, Published online: 19-06-2017

doi: 10.14202/vetworld.2017.667-671 How to cite this article: Pradeep J, Stephen S, Pooja P, Akshayavardhini A, Sangeetha B, Antony PX (2017) Coxiellosis in domestic livestock of Puducherry and Tamil Nadu: Detection of Coxiella burnetii DNA by polymerase chain reaction in slaughtered ruminants, Veterinary World, 10(6): 667-671.

\begin{abstract}
Background and Aim: In the course of our Indian Council of Medical Research project on coxiellosis in Puducherry and Tamil Nadu, $5.64 \%$ goat, $1.85 \%$ sheep, $1.06 \%$ buffaloes, and $0.97 \%$ cattle were positive for Coxiella burnetii antibodies by enzyme linked immunosorbent assay kit (IDEXX, Liebefeld, Switzerland). In this preliminary study, we have proceeded to look for $C$. burnetii DNA in those antibody positive specimens employing an imported commercial C. burnetii polymerase chain reaction (PCR) kit.

Materials and Methods: Blood samples were collected during slaughtering. All 15 blood samples of antibody positive ruminants and three antibody negative samples were subjected to conventional Trans-PCR assay with a commercial PCR kit (Genekam Biotechnology AG, Duisburg, Germany). An in-house Trans-PCR was included in the study for comparison.

Results: A total of 15 antibody positive and three antibody-negative serum samples belonging to 11 goat, 4 sheep, 1 cattle, and 2 buffaloes were tested in duplicate for the presence of $C$. burnetii DNA by the commercial agar gel PCR kit and an in-house Trans-PCR. Only one buffalo serum sample was positive for C. burnetii with a band at 243 bp in in-house Trans-PCR.

Discussion: Seropositivity for C. burnetii need not necessarily translate into infectivity status of the animal. Conversely, seronegative ruminants can shed $C$. burnetii. Rapid disintegration of $C$. burnetii DNA during the storage period is an important impediment in QF-PCR research. This is the first time the performance of this commercial PCR kit is being validated in India.
\end{abstract}

Conclusion: Commercial PCR kit, Genekam did not identify any positive sample, probably because it targeted a larger amplicon of $687 \mathrm{bp}$.

Keywords: Coxiella burnetii DNA, coxiellosis, Trans-polymerase chain reaction.

\section{Introduction}

To quote Kovacova and Kazar "Q fever - still a query and underestimated infectious disease" [1]. This disease is prevalent worldwide with the exception of New Zealand [2,3]. Coxiella burnetii, causative agent of $\mathrm{Q}$ fever is an obligate intracellular Gram-negative bacterium. It is a potential agent of bioterrorism and Category-B pathogen demanding bio-safety level-3 facilities for isolation/antigen preparation works [4-8]. Hence, only serological and molecular diagnostic

Copyright: Pradeep, et al. Open Access. This article is distributed under the terms of the Creative Commons Attribution 4.0 International License (http://creativecommons.org/licenses/ by/4.0/), which permits unrestricted use, distribution, and reproduction in any medium, provided you give appropriate credit to the original author(s) and the source, provide a link to the Creative Commons license, and indicate if changes were made. The Creative Commons Public Domain Dedication waiver (http:// creativecommons.org/publicdomain/zero/1.0/) applies to the data made available in this article, unless otherwise stated. tests are available to most of the laboratories in the world. Coxiellosis is a major zoonotic disease and it infects a wide spectrum of animals such as ruminants, dogs, cats, reptiles, wild animals, and birds [2,7-9]. Commonly the dog ticks (Rhipicephalus sanguineus) and occasionally snake ticks (Aponomma gervaisi) do harbor $C$. burnetii $[10,11]$ and may transmit infection to the animals but normally have no role to play in human illness. Interestingly, a report mentions that the crushing of infected tick between the fingers has resulted in Q fever [12]. Transmission of Q fever from farm animals is an important reservoir of human infections. It can transmit through inhalation/ingestion of aerosols by infected aborted materials, unpasteurized milk and its products $[8,13,14]$. In India, the first two cases of human Q fever were reported by Anderson and Kalra in 1954 [15] and Ghosh and Rao in 1956 [16], followed by countrywide serological 
surveys by Kalra and Taneja [17]. Two reviews of Q fever in man and animals of India appeared in 1978 and 1980, giving detailed account of seroprevalence as well as tests employed by earlier workers $[18,19]$. The late seventies and early eighties witnessed several reports of Q fever in human/animals from several states such as Punjab, Haryana, Rajasthan, Kerala, Karnataka, Uttar Pradesh, Maharashtra, Delhi, Orissa, and the latest from Rajasthan (2003), Tamil Nadu (2008), and Puducherry (2014) [20-32]. No serosurvey reports on coxiellosis in Indian animals appeared after the eighties, until the recent report of coxiellosis in small ruminants of Puducherry in 2014 [32]. Evidence of animal and human abortions, neonatal septicemia, endocarditis, and atypical pneumonia due to C. burnetii based on immunofluroescence test/polymerase chain reaction (PCR) are recorded in recent Indian literature $[4,5,33,34]$.

Intherecent times, coxiellosis in animalshave been reported from several countries such as Bangladesh, Iran, Brazil, Turkey, USA, Greece, Bulgaria, Switzerland, Italy, and The Netherlands $[14,35,36]$. An outbreak of Q fever in Danish goat, leading to killing of 51,680 infected goats and reports of coxiellosis in different countries across the globe have raised the awareness level of Q fever throughout the world [36]. Nearly, 583 abortions had occurred due to C. burnetii infection in small ruminants between 2002 and 2011. An observation of $C$. burnetii infection in Swiss animals by screening of milk samples shows that mostly it occurred in $<5 \%$ of cattle products and absent in sheep or goat samples [37].

Seroprevalence studies of coxiellosis in several countries including India were based on specific and sensitive serological tests such as capillary agglutination test, complement fixation test, enzymelinked immunosorbent assay (ELISA), indirect immunofluroescence assay, molecular tests like PCR, real-time PCR, and loop-mediated isothermal amplification [4-43]. Our aim of this preliminary communication is to examine a small number of seropositive ruminants for $C$. burnetii DNA. Evaluation of a commercial and imported conventional PCR kit is done for the first time in India and compared with an in-house prepared Trans-PCR.

\section{Materials and Methods \\ Ethical approval}

Institute's Animal Ethical Committee had given approval for this work.

\section{Study area}

This study was conducted in the Microbiology Department of a tertiary care super specialty teaching hospital at Puducherry during January 2014 to December 2015.

\section{Collection of blood samples}

Blood samples were collected from domestic livestock at the time of slaughtering from various private/government/municipal abattoirs as well as mutton shops located in different areas of Tamil Nadu and Puducherry. A total of 772 blood samples were collected comprising 216 sheep, 195 goat, 206 cattle, and 188 buffaloes.

\section{Test procedure for ELISA and PCR}

ELISA was performed with Q fever antibody ELISA Test Kit, (IDEXX, Liebefeld, Switzerland). The ELISA wells were coated with C. burnetii Phase I and II antigens and it was carried out as per the procedure outlined by the kit manufacturer and as per earlier report [6].

\section{DNA extraction}

About $200 \mu 1$ serum samples were used for the genomic DNA extractions as per the manufacturer's protocol. Carrier DNA was added to the serum sample before extraction to maximize DNA yield, as recommended by the protocol. The purity of the extracted DNA was determined by calculating absorbance (A) A260/A280 ratio, which was in the range of 1.7-1.8 for all the samples. The samples were aliquoted and stored at $-80^{\circ} \mathrm{C}$ till further use.

\section{Kit-based Trans-PCR}

Trans-PCR for the samples was done in duplicates using C. burnetii PCR kit (Genekam, Disburg, Germany) as per manufacturer's protocol. The reaction conditions for the PCR were as follows: Denaturation at $20 \mathrm{~s}$ at $95^{\circ} \mathrm{C}$, annealing for $60 \mathrm{~s}$ at $50^{\circ} \mathrm{C}$, and extension for $120 \mathrm{~s}$ at $72^{\circ} \mathrm{C}$ for 30 cycles. The PCR was carried out using $\mathrm{C} 1000$ Thermocycler, Bio-Rad, USA, and the PCR product was visualized on agarose gel by ethidium bromide staining.

\section{In-house Trans-PCR}

In-house PCR was carried out using primers (Sigma-Aldrich, Bengaluru) for amplifying IS1111 transposon-like repetitive element of $C$. burnetii $[2,9,10]$. The sequence of the primers used was Trans 1: 5'-TATGTATCCACCGTAGCCAGTC-3' and Trans 2: 5'-CCCAACAACACCTCCTTATTC-3'; Trans 3: 5'-GTAACGATGCGCAGGCGAT-3' and Trans 4: 5'-CCACCGCTTCGCTCGCTA-3'. The PCR reaction was carried out in $25 \mu \mathrm{l}$ of reaction mixture with $12.5 \mu 1 \times 2$ Taq DNA polymerase PCR kit (ampliqon), $1 \mu 1$ of forward primer and reverse primer each, $5 \mu 1$ template DNA, and $5.5 \mu 1$ molecular grade distilled water. The PCR conditions were as follows:

Denaturation at $95^{\circ} \mathrm{C}$ for $30 \mathrm{~s}$, annealing at $65^{\circ} \mathrm{C}$ for $40 \mathrm{~s}$ extension at $72^{\circ} \mathrm{C}$ for $30 \mathrm{~s}$ for 35 cycles, and a final elongation step at $72^{\circ} \mathrm{C}$ for $5 \mathrm{~min}$. The PCR was carried out using C1000 Thermocycler, Bio-Rad, USA and the PCR product was visualized on agarose gel by ethidium bromide staining.

\section{Results and Discussion}

In this study, we used four primers Trans 1, 2, 3 , and 4 which target IS1111 transposon-gene repetitive element for detection of $C$. burnetii in serum samples. 18 samples, 15 antibody positive, and three 
antibody-negative serum samples belonging to 11 goat, 4 sheep, 1 cattle, and 2 buffaloes were tested with ready to use conventional Genekam PCR kit with the primer set of Trans 1 and 2, with an expected amplicon size of $687 \mathrm{bp}$, but none of them were positive. The positive control provided in the kit, as well as C. burnetii DNA (Bioscience, Bratislava) gave clear band at $687 \mathrm{bp}$ (Figure-1). Negative controls were added in each run to avoid DNA contamination. When our in-house Trans-PCR was performed with primer set of Trans 1 and 2, all samples were negative except the positive controls. However, when the experiment was repeated with the second set of primers, viz., Trans 3 and 4, one seropositive buffalo had C. burnetii DNA (Figure-2).

In this study, we evaluated commercially available, ready to use $C$. burnetii conventional PCR for the first time in India and found it unsatisfactory for Indian ruminants, which is most likely because it targets a larger molecular weight amplicon size $687 \mathrm{bp}$. Q fever is on the increase and included in the list of notifiable diseases in some European countries [36,39].

Largest outbreak in Bulgaria and Europe lead to the investigators to find out a high seroprevalence of C. burnetii antibodies in humans as well as animals $[36,42]$. According to Bellini et al., only $14 \%$ C. burnetii antibody positive (by ELISA) ruminants had $C$. burnetii DNA in the real time PCR assay [44]. However, Kargar et al. reported that the primers Trans 1 and 2 are highly sensitive and showed $17.14 \%$ positivity when

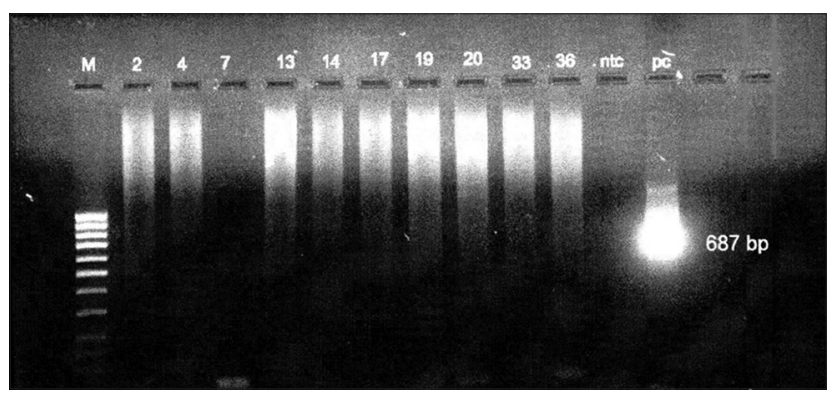

Figure-1: Coxiella burnetii Genekam conventional polymerase chain reaction. m - DNA ladder 100 bp; 2, 4, $7,13,14,17,19,20,33,36$ - Negative; ntc - negative control; pc - positive control (687 bp).

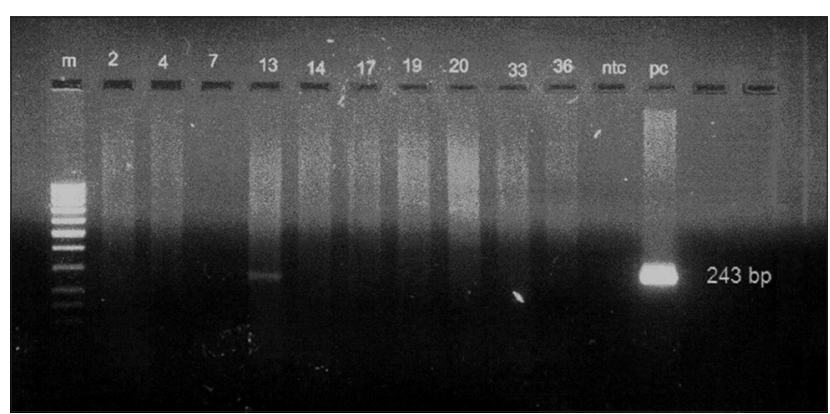

Figure-2: Coxiella burnetii in-house Trans-polymerase chain reaction (Trans 3 and 4 primers). m - DNA ladder 100 bp; 2, 4, 7, 14, 17, 19, 20, 33, 36 - Negative; 13 - Positive for C. brunetti DNA; ntc - negative control; pc - positive control (243 bp). compared with Com 1 and Coc-PCR with only $10 \%$ positivity for milk products [9]. However, Kılıç et al. reported that Trans 1 and 2 PCR could detect only 2\% C. burnetii DNA in the organs of infected animals and observed that IS1111 gene was circulating among the domestic sheep and goat [40]. Gunaydin et al. reported that Trans PCR 687 bp displayed a negative result in animal serum samples which are seropositive for $C$. burnetii antibodies [45]. According to a recent report by Chakarabarthy et al., the overall seroprevalence of coxiellosis in Bangladesh was 7.6\% and $6.1 \%$ for goats and cattle, respectively. However, none of seropositive samples were positive for $C$. burnetii DNA in real-time PCR [35]. Two researchers observed that $C$. burnetii appears to be quite frequent in blood as well as milk products of cattle $[14,35]$. Kim et al. accounted year wise prevalence of coxiellosis in milk products of cattle as $52.8 \%, 23.5 \%$, and $31.3 \%$ in 2002,2003 , and 2004, respectively [14].

There is not much of a progress in India in the molecular diagnosis of coxiellosis/Q fever, except for few reports from Uttar Pradesh, Karnataka, and Tamil Nadu [4-7,31,34]. By the application of molecular diagnosis using Trans-PCR, Indian researchers reported prevalence of Q fever $21.6 \%$ of human abortions, $11.05 \%$ of domestic animals with reproductive disorders, and $2.8 \%$ of patients with atypical pneumonia $[4,5,34]$. Our study points to the fact that Trans 3 and 4 are sensitive than Trans 1 and 2, as it is a short fragment in the most conserved region of $C$. burnetii DNA. Use of 243 bp or even smaller $70 \mathrm{bp}$ amplicon [34] could perhaps pick up more positive cases in humans as well as domestic livestock. Das et al. isolated C. burnetii from the aborted fetuses of $4.54 \%$ cattle and $8.33 \%$ buffaloes [6]. IS1111 Transposonrepetitive element is best known target for detection of $C$. burnetii DNA in patients with active infections $[6,40]$. Degradation of preserved C. burnetii DNA is a major drawback in the molecular diagnosis of coxiellosis. It is known that while $C$. burnetii antibody positive animals need not necessarily shed this organism, antibody negative livestock can shed this bacterium in their secretions/excretions [32]. In our preliminary work, only a small number of 18 ruminants' serum samples were used for detection of $C$. burnetii DNA. The study could be expanded to cover more number of animals so as to get a better and clear picture of the prevalence of this zoonosis.

\section{Conclusion}

This preliminary communication records a low $(6.67 \%)$ C. burnetii DNA among antibody positive ruminants. The use of smaller amplicon size of $243 \mathrm{bp}$ and perhaps even much smaller ones might result in a higher percentage of positivity. The large sized amplicon of $687 \mathrm{bp}$ is perhaps a reason for the failure of the commercial kit to detect any positive case. 


\section{Authors' Contributions}

SS, JP, PXA planned, designed, and conducted data interpretation. BS and JP performed sample collection. BS, JP, AA carried out sample analysis. PXA and PP edited the manuscript. All authors read and approved the final manuscript.

\section{Acknowledgments}

Corresponding author(Selvaraj Stephen) is thankful to Indian Council of Medical Research for providing Research grant for this Rickettsial Project (IRIS ID no.: 2008-08180; File no. - 30/3/41/2008/ECD-II) and also express sincere gratitude to the Chairman, Vice-Chancellor, Dean (Faculty of Medicine and PG) and Dean (Research and AHS) of Mahatma Gandhi Medical College and Research Institute, Puducherry, for their encouragement and financial support provided for this Sri Balaji Vidyapeeth University Faculty Research Project.

\section{Competing Interests} interests.

The authors declare that they have no competing

\section{References}

1. Kovácová, E. and Kazár, J. (2002) Rickettsial diseases and their serological diagnosis. Acta Virol., 46(5-6): 193-210.

2. World Organization for Animal Health. Manual of Diagnostic Tests and Vaccines for Terrestrial Animals; 2013. Available from: http://www.oie.int/international-standard setting/terrestrial-manual/Access-online. accessed on 13-06-2016.

3. Hilbink, F., Penrose, M., Kovacova, E. and Kazar, J. (1993) Q fever is absent from New Zealand. Int. J. Epidemiol., 22(5): 945-949.

4. Vaidya, V.M., Malik, S.V.S., Bhilegaonkar, K.N., Rathore, R.S., Kaur, S. and Barbuddhe, S.B. (2010) Prevalence of Q fever in domestic animals with reproductive disorders. Comp. Immunol. Microbiol. Infect. Dis., 33(4): 307-321.

5. Vaidya, V.M., Malik, S.V.S., Kaur, S., Kumar, S. and Barbuddhe, S.B. (2008) Comparison of PCR, IF, pathology and isolation for $\mathrm{Q}$ fever in humans with spontaneous abortion. J. Clin. Microbiol., 46(6): 2038-2044.

6. Das, D.P., Malik, S.V.S., Rawool, D.B., Das, S., Shoukat, S., Gandham, R.K., Saxena, S., Singh, R., Doijad, S.P. and Barbuddhe, S.B. (2014) Isolation of Coxiella burnetii from bovines with history of reproductive disorders in India and phylogenetic inference based on the partial sequencing of IS1111 element. Infect. Genet. Evol., 22: 67-71.

7. Das, D.P., Malik, S.V.S., Mohan, V., Rawool, D.B. and Barbudhe, S.B. (2013) Screening of fecal droppings of wild birds for coxiellosis by a duplex PCR targeting Com1 and IS1111 genes of Coxiella burnetii. J. Food Borne Zoonotic Dis., 1(1): 14-20.

8. Prasad, B.N., Chandiramani, N.K. and Wagle, A. (1986) Isolation of Coxiella burnetii from human sources. Int. J. Zoonoses, 13(2): 112-117.

9. Kargar, M., Rashidi, A., Doosti, A., Najafi, A. and GhorbaniDalini, S. (2015) The sensitivity of the PCR method for detection of Coxiella burnetii in the milk samples. Zahedan J. Res. Med. Sci., 17: 29-32.

10. Stephen, S., Chandrashekara, I. and Rao, K.N. (1980) Natural occurrence of Coxiella burnetii in the brown dog tick Rhipicephalus sanguineus. Indian J. Med. Res., 71: 865-869.
11. Stephen, S. and Rao, K.N.A. (1979) Q fever in South Kanara district: Natural occurrence of Coxiella burnetii in the tick (Aponomma gervaisi)--preliminary report. Indian J. Med. Res., 69: 244-246.

12. Mediannikov, O., Fenollar, F., Socolovschi, C., Diatta, G., Bassene, H. and Molez, J.F., Sokhna, C., Trape, J.F. and Raoult, D. (2010) C. burnetii in humans and ticks in rural sengal. PLoS. Negl. Trop. Dis., 4(4): e654.

13. Muskens, J., Engelen, E.V., Maanen, C.V., Bartels, C. and Lam, T.J.G. (2011) Prevalence of Coxiella burnetii infection in Dutch dairy herds based on testing bulk tank milk and individual samples by PCR and ELISA. Vet. Rec., 168(3): 79.

14. Kim, S.G., Kim, E.H., Lafferty, C.J. and Dubovi, E. (2005) Coxiella burnetii in bulk tank milk samples, United States. Emerg. Infect. Dis., 11(4): 619-621.

15. Anderson, P.K. and Kalra, S.L. (1954) Q fever studies in India: A case of human Q fever. Indian J. Med. Res., 42: 307-313.

16. Ghosh, B. and Rao, K.N.A. (1956) 'Q' fever - A case report. AF. Med. J. India, 12: 27-33.

17. Kalra, S.L. and Taneja, B.L. (1954) Q fever in India: A serological survey. Indian J. Med. Res., 42(3): 315-318.

18. Padbidri, V.S. and Gupta, N.P. (1978) Riskettsiosis in India: A review. J. Indian Med. Assoc., 71(4): 104-107.

19. Stephen, S. and Rao, K.N.A. (1980) Q fever in India: A review. J. Indian Med. Assoc., 74(10): 200-202.

20. Randhawa, A.S., Dhillon, S.S. and Jolley, W.B. (1973) Serologic prevalence of Q fever in the state of Punjab, India. Am. J. Epidemiol., 97(2): 131-134.

21. Sodhi, S.S., Joshi, D.V., Sharma, D.R. and Baxi, K.K. (1980) Seroprevalence of brucellosis and Q fever in dairy animals. Zentralbl. Veterinarmed. B., 27(8): 683-685.

22. Joshi, M.V., Padbidri, V.S., Rodrigues, F.M. and Gupta, N.P. (1979) Prevalence of Coxiella burnetii infection among humans and domestic animals of Rajasthan State, India. J. Hyg. Epidemiol. Microbiol. Immunol., 23(1): 67-73.

23. Shanmugam, J., Raveendranath, M. and Sukumaran, M. (1978) Seroprevalence of Q fever infection in human beings from southern region of Kerala State. Indian J. Med. Res., 67: 217-220.

24. Joshi, M.V., Menon, R.D., Padbidri, V.S. and Manjrekar, S.L. (1975) A note on the serological evidence of ' $Q$ ' fever in sheep from Karnataka State. Indian J. Anim. Sci., 45(1): 54-55.

25. Stephen, S., Indrani, R. and Rao, K.N.A. (1978) Q fever antibodies in domestic animals in South Kanara - A preliminary report. Indian J. Med. Res., 68: 39-43.

26. Stephen, S. and Rao, K.N. (1979) Coxiellosis in reptiles of South Kanara district, Karnataka. Indian J Med Res. 70:937-41.

27. Stephen, S., Chandrashekara, I., Rao, H.L., Rao, K.G. and Rao, K.N. (1980) Prevalence of human Q fever in South Kanara district, Karnataka. Indian J. Med. Res., 71: 510-515.

28. Yadav, M.P. and Sethi, M.S. (1979) Sero-epidemiological studies on coxiellosis in animals and man in the state of Uttar Pradesh and Delhi (India). Int. J. Zoonoses, 6(2): 67-74.

29. Padbidri, V.S., Rodrigues, F.M., Vidyasagar, J. and Joshi, M.V. (1981) Prevalence of antibodies to Coxiella burnetii among the domestic animal population in Orissa. Indian J. Med. Vet., 5(3): 99-103.

30. Rao, R. (2003) Seroprevalence of human coxiellosis Q-fever in Bikaner district of Rajasthan. J. Vet. Public Health, 1: 135-139.

31. Balakrishnan, N., Menon, T., Fournier, P.E. and Raoult, D. (2008) Bartonella quintana and Coxiella burnetii as causes of endocarditis, India. Emerg. Infect. Dis., 14(7): 1168-1169.

32. Stephen, S., Sangeetha, B. and Antony, P.X. (2014) Seroprevalence of coxiellosis (Q fever) in sheep and goat in Puducherry and neighbouring Tamil Nadu. Indian J. Med. 
Res., 140(6): 785-787.

33. Aarthi, P., Bagyalakshmi, R., Mohan, K.R., Krishna, M., Nitin, M., Madhavan, H.N. and Kalyani, S. (2013) First case series of emerging rickettsial neonatal sepsis identified by polymerase chain reaction-based deoxyribonucleic acid sequencing. Indian J. Med. Microbiol., 31(4): 343-348.

34. Gangoliya, S.R., Kumar, S., Alam, S.I., Devi, D.R.G. and Guchhait, P. (2016) First molecular evidence of Coxiella burnetii in patients with atypical pneumonia, India. J. Med. Microbiol., 65(3): 255-256.

35. Chakarabarthy, A., Bhattacharjee, P.K., Sarker, R.R., Rahman, A.K.M., Henning, K., Neubauer, H. and Rahman, M.S. (2016) Prevalence of Coxiella burnetii infection in cattle, black bengal goats and ticks in Bangladesh. Bangladesh J. Vet. Med., 14(1): 65-68.

36. van der Hoek, W., Dijkstra, F., Schimmer, B., Schneeberger, P.M., Vellema, P., Wijkmans, C., Ter Schegget, R., Hackert, V. and van Duynhoven, Y. (2010) Q fever in the Netherlands: An update on the epidemiology and control measures. Eur. Surveill., 15(12): 19520.

37. Fretz, R., Schaeren, W., Tanner, M. and Baumgartner, A. (2007) Screening of various foodstuffs for occurrence of Coxiella burnetii in Switzerland. Int. J. Food Microbiol. 116(3): 414-418.

38. Edalati-Shokat, H., Abbasi-Doulatshahi, E., HajianBidar, H., Gharekhani, J. and Rezaei, A.A. (2015) Q fever in domestic ruminants: A seroepidemiological survey in hamedan, Iran. Int. J. Curr. Microbiol. Appl. Sci., 4(1): 589-596.

39. Mares-Guia, M.A., Rozental, T., Guterres, A., Gomes, R.,
Almeida, D.N., Moreira, N.S., Barreira, J.D., Favacho, A.R., Santana, A.L. and Lemos, E.R. (2014) Molecular identification of the agent of $\mathrm{Q}$ fever-Coxiella burnetii-in domestic animals in State of Rio de Janeiro, Brazil. Rev. Soc. Bras. Med. Trop., 47(2): 231-234.

40. K1lıç, A., Kalender, H., Koç, O., Kılınç, Ü., Irehan, B. and Berri, M. (2016) Molecular investigation of Coxiella burnetii infections in aborted sheep in eastern Turkey. Iran. J. Vet. Res., 17(1): 41-44.

41. Bisias, G., Burriel, A.R., Boutsini, S., Kritas, S.K. and Leontides, L.S. (2010) A serological investigation of some abortion causes among small ruminant flocks in Greece. Internet J. Vet. Med., 8(2): 1-7.

42. Panaiotov, S., Ciccozzi, M., Brankova, N., Levterova, V., Mitova-Tiholova, M., Amicosante, M., Rezza, G. and Kantardjiev, T. (2009) An outbreak of Q fever in Bulgaria. Ann. Ist. Super. Sanita., 45(1): 83-86.

43. Raele, D.A., Garofolo, G., Galante, D. and Cafiero, M.A. (2015) Molecular detection of Coxiella burnetii using an alternative Loop-mediated isothermal amplification assay (LAMP). Vet. Ital., 51(1): 73-78.

44. Bellini, C., Magouras, I., Chapuis-Taillard, C., Clerc, O., Masserey, E., Peduto, G., Peter, O., Schaerrer, S., Schuepbach, G. and Greub, G. (2014) Q fever outbreak in the terraced vineyards of Lavaux, Switzerland. N. Microbe. N. Infect., 2(4): 93-99.

45. Gunaydin, E., Pekkaya, S., Mustak, H.K. and Dalkilic, B. (2014) Investigation of Q fever in Kilis and Shamil goats by ELISA and touchdown-PCR. Ankara Univ. Vet. Fak. Derg., 61(3): 161-165. 